\title{
Beyond Secularism: Orhan Pamuk's Snow and the Contestation of 'Turkish Identity' in the Borderland
}

Ülker Gökberk

Reed College

This paper explores the multifaceted discourse on Islam in present-day Turkish society, as reflected upon in Orhan Pamuk's 2002 novel Snow. The revival of Islam in Turkish politics and its manifestation as a lifestyle that increasingly permeates urban environments, thus challenging the secular establishment, has occasioned a crisis of 'Turkish identity'. At the core of this vehemently contested issue stands women's veiling, represented by its more moderate version of the headscarf. The headscarf has not only become a cultural marker of the new Islamist trend, it has also altered the meanings previously attached to socio-cultural signifiers. Thus, the old binaries of 'tradition' and 'modernity,' 'backwardness' and 'progress,' applied to Islamic versus Western modes of living and employed primarily by the secularist elites and by theorists of modernization, prove insufficient to explain the novel phenomenon of Islamist identity politics. New directions in social and cultural theory on Turkey have launched a critique of modernization theory and its vocabulary based on binary oppositions. I argue that Pamuk participates, albeit from the angle of poetic imagination, in such a critique. In Snow the author explores the complexities pertaining to the cultural symbolism circulating in Turkey. The ambiguity surrounding the headscarf as a new cultural marker constitutes a major theme in the novel. I demonstrate that Snow employs multiple perspectives pertaining to the meaning of cultural symbols, thus complicating any easy assessment of the rise of Islam in Turkey. By withholding from the reader a clear guide to unequivocal judgment of right and wrong, the author transcends the parameters of Turkish modernist ideology.

Pamuk situates his story in Kars, a border city in North-Eastern Turkey. This location at the geographical and cultural margins of Turkey emerges in the novel as a complex site of contested ideological, political, and metaphysical positions pertaining to the question of Turkish identity. It represents a space where Islamic faith in its esoteric and exoteric forms is carried out over against state-imposed laicism. I argue that it is the other-worldliness of the locale that instigates such a reflection. The protagonist $K a$, a Turkish poet who has briefly returned to his hometown, Istanbul, after twelve years of exile in Germany, embarks on a journey to Kars. A member of the secular Istanbul bourgeoisie, Ka seems to be afflicted by an ailment common to his social stratum, a vacuum of spiritual values. Even though Ka travels to Kars with a journalistic mission, he soon becomes entrapped in this alien world of Sheiks, head-scarved girls, and former communists turned political Islamists. The novel oscillates between the Ka's perspective as a detached observer and his personal quest to find transcendence. By employing multiple perspectives, Pamuk complicates any easy assessment of the rise of Islam in today's Turkish society. I complement this reading of Snow with a brief excursus to Pamuk's recent memoir, Istanbul: Memories and the City, permeated by the author's critique of the modernist ideology of the Republican era. This critique sheds light on Pamuk's opaque discourse on faith in Snow. These two books by the Nobel-prize winner have been his most disputed ones among the Turkish secular intelligentsia. I conclude with a reference to these critical commentaries. 
There is a great deal of theology in Orhan Pamuk's novel Snow.' Basic theological questions, such as the existence of God, heaven and hell, and the consequences of atheism are addressed with stunning directness, both through the interlocutions of the characters and the musings of the narrator. Yet, the author undermines the serious and sincere articulation of religious issues by employing diverse narrative modes and strategies, such as psychological realism, intertextuality, irony, and the alternation of first-person and figural narration, that relativize but never fully cancel the signification of faith in the novel. ${ }^{2}$ Since this theological discourse predominantly pertains to Islam, two questions arise (against the backdrop of today's widespread global image of radicalized Islam): Does theology become politics in Snow, and if this is the case, does it turn violent? Even though violence constitutes a core element of the rich thematic net of the novel, used by all players, not only the Islamists, I would argue that Snow is not about Islam and violence. Instead, the author subsumes these themes under a broad novelistic inquiry on politics of identity. Snow represents a microcosm that mirrors, even if in a deliberately distorted fashion, Turkey's recent history, cultural politics, and renewed external and internal struggle for self-definition. As Pamuk puts it, "Novels are neither wholly imaginary nor wholly real. To read a novel is to confront its author's imagination and the real world whose surface we have been scratching with such fretful curiosity." The novel reenacts multiple standpoints emerging from this struggle, without offering the reader any clear guide to unequivocal judgment of right and wrong.

In the following analysis, I read Snow as a narrative construed on the delicate balance between socio-political commentary and the use of literary tropes and themes, revolving around identity and displacement. While the commentary pertains to Turkish society, the "real world" of the author, Pamuk's treatment of themes, such as exile, selfhood, oppression, and marginalization resonate with theoretical issues explored in cultural theory. I argue that these intertwined layers of the novel help illustrate the intrinsic linkage Pamuk establishes between the representation of social reality and multiple facets of the question of identity. By moving on a spatiotemporal scale that extends from Frankfurt, Germany to the remote province of Kars in Turkey, the novel intriguingly connects disparate exilic modes and uncovers parallels between seemingly 
unrelated moments of marginalization, such as the Turkish and Kurdish milieu of Gastarbeiter and refugees in Frankfurt; the poet Ka, a Turkish political exile in Germany; the Armenian past; and the followers of the Islamist movement of Turkey. As I will demonstrate in my analysis, Snow is the first Turkish novel written by a member of the secular intelligentsia, in which the 'counter public' of Islamists is represented in individual nuances, given a human face and a voice. The novel achieves such a representation of particularities by placing all characters into exilic spaces, thereby relativizing the constellation of center and margin that in the Turkish context traditionally stands for the position of the ruling urban elites versus uneducated, religious masses. Accordingly, the socio-political commentary emerging from Snow's intertwined thematic structure contains a critique of the dominant secularist view for its one-dimensional and exclusive model of 'Turkish identity.' To be sure, Pamuk does not deliver such a critique as the single, unambiguous message of the novel; he rather formulates it through a wider spectrum of exilic themes. ${ }^{4}$

In the following I first examine Pamuk's critical assessment, albeit from the angle of poetic imagination, of the contested notion of 'Turkish identity.' I argue that Pamuk participates from the vantage point of Snow's fictional universe in the critique of modernization theory, brought forward by social and cultural theorists since the 1980s. In order to illustrate this point, I outline the main tenets of the new directions in social and cultural theory on Turkey. Distancing themselves from dualistic models, scholars representing the new directions investigate the transformations Turkish society has undergone since the foundation of the Republic in 1923 under a pluralistic viewpoint. Accordingly, they investigate, in a similar vein to Pamuk, the relatively novel phenomenon of Islamist identity politics beyond the premises of the secularist vocabulary. Rejecting as reductive the binarisms, such as 'tradition' and 'modernity,' used by followers of the modernization project, these critics propose to explain manifestations of Islamic identity in the public sphere through more complex models. By situating the question of Islamist identity politics in the framework of the topic of displacement, Pamuk lays out the complexities and ambiguities surrounding the perception of the new mode of Islam, thereby resonating the above-mentioned critics. Among the cultural symbols defining Islamist identity politics, the headscarf undoubtedly 
has surfaced as the most controversial one in Turkish public discourse and has been scrutinized by the above-mentioned critics as a polyvalent cultural marker. At the present, Turkey's democratic future seems to be depending on the question of the legitimization of the headscarf. ${ }^{5}$ Pamuk's Snow, published in 2002, foreshadows the current political crisis by presenting a story in which the conflicting significations of the headscarf propel the action.

The revival of Islam in Turkish politics since the late 1980s and its manifestation as a lifestyle that increasingly permeates urban environments, thus challenging the secular establishment, has occasioned a crisis of 'Turkish identity. ${ }^{6}$ Sociologist Resat Kasaba defines the Islamic resurgence in the broader context of Turkish people's turning away from the modernization program:

This reorientation of the social compass spread to all segments of the society, not only affecting people's political outlook but also influencing the way they dressed, which music they created and listened to, how they built their houses and office buildings, and how they thought about the history of modern Turkey. ${ }^{7}$

At the core of the fervent dispute on 'Turkish identity' stands women's veiling or covering (tesettür), represented by its more moderate version of the headscarf. This head cover has not only become a cultural marker of the new Islamist trend in Turkey, it has also altered the meanings previously attached to socio-cultural signifiers. Scholars who take issue with the modernization model have argued that the old binaries of 'tradition' and 'modernity,' 'backwardness' and 'progress,' applied to Islamic versus Western modes of living and asserted by the secularist ruling elites and by theorists of modernization, prove insufficient to explain the novel phenomenon of Islamist identity politics. As Deniz Kandiyoti points out, recent scholars of Ottoman-Turkish history scrutinize such a linear teleological narrative that portrays the transformation of Turkish society as an evolution from 'rural' to 'urban,' from 'less developed' to 'more developed,' or from 'traditional' to 'modern.' Instead of offering such an unambiguous narrative, current scholarship focuses on the "messiness and complexity of social transformation" that Turkey underwent from its genesis in the 1920s to the present. ${ }^{8}$ 
Nilüfer Göle's distinction between the traditional Islamic practice of women's covering their heads and most of their bodies and the new, 'conscious' practice of Islamic dress (headscarf and a long overcoat) sheds light on the complexity of this novel cultural signification and identity politics. In conjunction with Göle, Jenny B. White explains:

Tesettür, as a form of cultural Islam, is perceived to be not only a marker of difference from the secularist elites, but also from the masses. Implicit in the strategic deployment of symbols to reposition oneself in a hierarchy of social stratification is a rupture from local practice where those same symbols - the disposition of the body, movement in space, and interpersonal relations - are embedded in a community and identity from which the new elites must distance themselves. ${ }^{9}$

Even though White agrees with Göle's analysis of the new Islamist elite whose women refashion themselves as distinct from traditional values of the masses and for whom covering (their heads and bodies in the new fashion) signifies urbanity, education, and upward mobility, White argues that elite Islamist activism and Islamic populism, i.e. the Islamic practices of the masses, interpenetrate in several instances. She demonstrates succinctly that the Islamic garments are worn across social classes for a variety of motivations, and, "diluting the association of clothing and lifestyle with meaning even further, many modern middle-class secularists, although not veiled, lead consciously Islamic lives associated with veiling." ${ }^{0}$ The inherent contradiction in tesettür consists, according to White, in its signification of a new elite of Islamist women along with its opposite meaning, posited by men and confining women to the private sphere of home. In line with this argument, we encounter in Snow spokesmen of the secularist view who oppose the headscarf as an indication of coercive religious practices, along with proponents of Islamism who define it as an essential part of their self-determined identity.

My discussion of the shifting meanings of the headscarf highlights an arena of a multifaceted cultural symbolism, through which Pamuk creates his novelistic discourse echoing the inherent conflicts of Turkey's cultural politics. Before embarking on the analysis of Snow, it may be useful to revisit the entangled meanings the words 'modern' 
and 'traditional' have acquired in the Turkish public sphere: While the modernists and secularists still adhere 'modern' to a Western-oriented mentality and lifestyle, from which religion is excluded, and view the manifestation of religious symbols as 'traditional' or 'backward,' the new Islamist activists, especially women, perceive themselves as 'modern' in a new sense. In order to establish an elite status, they attribute 'tradition' to the unselfconscious practice of Islam by the masses."

To what extent and how does Pamuk explore this complexity? His oeuvre is dedicated to themes such as Turkey's stance between East and West; its Ottoman past and Western-oriented present; conflicts arising from old and new definitions of the artist, of faith and a non-religious lifestyle. Even though these themes seem to imply binary oppositions, Pamuk complicates dualities through various strategies, most notably the doubling of his fictional characters and their switching of identities. ${ }^{12}$ In congruence with his other works, the author challenges in Snow binary modes of explanation on several layers. As I previously indicated, one such layer pertains to the configurations of 'self' and 'other.' I should also note that, despite the increasing presence of Islamists in Turkish society, and notwithstanding the fact that an Islamist party holds the political power, the question of 'othering,' manifest in the secularist elite's fight against Islamist identity politics, still remains a crucial one. Against this backdrop, Snow addresses the multifaceted question of the 'other' as a central topos, displaying the instability of its boundaries from various angles. In his essay "In Kars and Frankfurt," Pamuk describes the motivation of his travels to the cities Frankfurt and Kars, that constitute the two poles of displacement in Snow, as "the chance to write of others' lives as if they were my own. It is by doing this sort of thorough novelistic research that novelists can begin to test the lines that mark off that 'other' and in doing so alter the boundaries of our own identities. Others become 'us' and we become 'others." In Pamuk's view, "putting ourselves in other's shoes" through the imaginative realm of the novel brings with itself a liberating effect. In this process, the 'other' as a figment of our own creation is undone. "The novelist will also know that thinking about this other whom everyone knows and believes to be his opposite will help to liberate him from the confines of his own persona."13 Applied to Snow, the statement illuminates Pamuk's approach to the 
new Islamist movement, the center of the contested 'Turkish identity,' from the vantage point of a broader reflection on alterity.

This leads us to the second component of Snow's intertwined thematic strands, the trope of exile. In the opening of his seminal essay "Reflections on Exile," Edward Said defines exile in its double bind, as a state of immense sorrow and loss, yet at the same time a powerful motif of modern culture. ${ }^{14}$ The 2006 Nobel-Prize laureate Orhan Pamuk was born in 1952 in Istanbul. With the exception of his intermittent teaching at universities in the United States, Pamuk has never lived away from his city of birth that he passionately loves. He was raised in a wealthy family of Turkish secular establishment, educated at an American secondary school for the social elites, and attended the Istanbul Technical University to become an architect, a career which he later abandoned in favor of writing. Even before his Nobel Prize award, he had acquired the stature of "both a best-selling author and an avant-garde writer." ${ }^{\prime 5}$ A much celebrated and contested public figure in his homeland, each of his new publications are embraced as a media sensation. It seems that Pamuk's life and public fame couldn't be farther away from the figure of the exiled writer, as portrayed by the Russian-Jewish poet and Nobel laureate Joseph Brodsky. ${ }^{16}$ According to Brodsky, the life of the exiled writer in the West could only be written as tragicomedy. The exile is fully capable of appreciating the social and material advantages of his new democratic environment. "Yet for precisely the same reason (whose main byproduct is the linguistic barrier) he finds himself totally unable to play any meaningful role in his new society. The democracy into which he has arrived provides him with physical safety but renders him socially insignificant. And the lack of significance is what no writer, exile or not, can take."

Since his biography and internationally recognized significance bear no resemblance to Brodsky's exiled writer, Pamuk's interest in exile could at first be understood as a pure literary engagement. Thus, following Said's double-faced definition, we may conclude that the multiple tropes of exile in Snow indicate Pamuk's selfpositioning in the modern Western literary tradition. In his essay on exile, Said alludes to critic Georg Steiner's thesis “that a whole genre of twentieth-century Western literature is 'extraterritorial,' a literature by and about exiles, symbolizing the age of refugee."18 My reading of Snow as a novel of extraterritoriality suggests that Pamuk 
utilizes this major trope of the Western literary canon. However, the prevalence of 'exile' throughout Pamuk's oeuvre indicates that this "potent, even enriching, motif of modern culture" ${ }^{19}$ serves a specific purpose within Pamuk's thematic repertoire. It should be emphasized that the author's preoccupation with states of estrangement and displacement is closely connected to his critique of Turkey's cultural transformation. Consequently his treatment of 'exile' always relates to this specific context while also implying universal connotations. Pamuk's memoir Istanbul, published in Turkish in 2003, a year after Snow, attests the author's appropriation of this theme in his construction of selfhood at a deeply personal level. ${ }^{20}$ To be sure, the autobiographic persona "Orhan" in the memoir is only "homeless" in a metaphorical sense in his otherwise well-protected and comfortable life. Pamuk seems to follow Steiner's dictum that the poets "in a civilization of quasi barbarism, which has made so many homeless, should themselves be poets unhoused and wanderers across language. Eccentric, aloof, nostalgic, deliberately untimely. .."2। While the sense of displacement Pamuk evokes in Istanbul represents the condition of the modern poet, it also serves as the premise of Pamuk's cultural critique, pertaining to a specific turn in Ottoman-Turkish history: the radical break with the imperial past with the foundation of the nation state. It is the consciousness of this irrevocable loss that reverberates in Pamuk's construction of individual and collective selfhood. Conjuring up Said's view of exile as an "unhealable rift," Istanbul projects this estrangement into the persona of its author's native city, portraying its denizens in a state similar to the unsurmountable sadness in Said's depiction. In Pamuk's representation, Istanbul is permeated with a collective melancholy (hüzün) over the city's bygone Ottoman past. The void ensuing upon the loss seems to hover over the city, since no meaningful values have replaced the old cultural tradition. ${ }^{22}$ Extraterritoriality becomes in Pamuk's oeuvre the signifier of the contested modern 'Turkish identity,' for in his universe, everybody seems to be affected by the abrupt erasure of the past. As a member of the secular elites, the autobiographical self in the memoir suffers under a sense of void, just like his kin, the main character Ka, in Snow. Both the memoir and the novel address the ruling classes' contempt of the pious masses they consider primitive and backward. The new Islamists, on the other hand, define 
themselves as 'modern,' by distancing themselves from the masses, while ostracized by the secular elites. ${ }^{23}$

In Snow, exile manifests itself in a tri-partite spatial axis, consisting of Frankfurt, Germany, Kars, the remote border province in North Eastern Turkey where the main story is set, and vague reminiscences of Istanbul, home of the narrator Orhan and former home of the protagonist Ka. The spatial configuration, around which the story evolves, is complemented by a temporal axis traversing between the Ottoman past and modern Turkey's present. As I will discuss later, Kars constitutes the intersection of these spatial and temporal components, functioning as a multivalent cipher of extraterritoriality.

The protagonist Kerim Alakusoglu, alias $\mathrm{Ka}$, is a Turkish poet who had to flee to Germany in the wake of the military coup of 1980 due to a political article he had not even written himself. Exiled in Frankfurt for twelve years, Ka comes to Istanbul in the early 1990s to attend his mother's funeral. Before returning to Germany, he decides to embark on a journey to the border city of Kars in order to explore recent political killings and suicides by young Muslim girls there, a journalistic mission he assumes on behalf of the Kemalist newspaper Cumhuriyet (Republic). As the reader gradually finds out, however, this is only the most obvious motif of the journey along with several more obscure ones, revealed in the course of the story. If the author Pamuk seems to have been spared the predicament of displacement, his hero $\mathrm{Ka}$ is the quintessential exiled writer, whose unbearable lot is portrayed by Brodsky as becoming insignificant. During a conversation about God with the Islamist student Necip in Kars, the student dismisses Ka's reassurance that he felt happy in Kars and wanted to be like everybody else in the city. ''Because you belong to the intelligentsia,' said Necip. 'People in the intelligentsia never believe in God. They believe in what Europeans do, and they think they're better than ordinary people.' 'I may belong to the intelligentsia in Turkey,' said Ka. 'But in Germany I'm a worthless nobody. I was falling apart there”" (103). In a later chapter, Ka envisions the prospect of returning to Frankfurt as "scurrying like a rat back into that hole in Frankfurt" (247). Ka remains a solitary figure in Frankfurt, even among the Turkish community, including political exiles like himself. He has contact with them only at occasional poetry readings. "His fellow exiles had found $\mathrm{Ka}$ too remote and too 
bourgeois" (256). Aside from the occasional readings, he lives surrounded by silence (he never learned German), spending most of his time at the Stadtbibliothek, reading Russian novels and English poetry. Several years before his journey to Kars, his poetic inspiration had also dried out.

The narrator-novelist Orhan visits Frankfurt after Ka's death in order to gather his friend's belongings. As we find out from his report, the apartment building where the exiled poet lived embodies through its flaking paint, gloomy interiors with broken furniture, and a xenophobic German landlord, the marginalized existence of the displaced. The narrator figure, who shares with the author Orhan Pamuk the same first name and the fortune of not having to leave his native city, observes the "loneliness and defeat so commonly seen in first-generation immigrants and political exiles," when he meets another Turkish expatriate in Frankfurt (25I). ${ }^{24}$ The narrator walks down the district between the train station and the Hauptwache square, depicting the Turkish and Kurdish kebab restaurants, fruit and vegetable stands, grocery shops selling, among other items, religious literature, and sex shops. This triste multicultural setting is rendered arguably the most treacherous site in the novel, for it is also the locale where $\mathrm{Ka}$ is killed four years after his return from Kars. All clues suggest that $\mathrm{Ka}$ is murdered at the hands of radical Islamists as the revenge of his alleged betrayal of the character called Blue. Blue whom Ka encounters in Kars remains an enigmatic figure. Secularists portray him as a terrorist, the sisters Ipek and Kadife, both of whom have had a love affair with him, as a pure idealist. Ka's act of betrayal, omitted from the narrative and suggested only by the course of events, entails primarily jealousy and passion, not political motivations. By enveloping the binary opposition between the Westernized individual and the radical Islamist into a love story, Pamuk complicates reading both characters' demise in purely political terms.

While Germany offers no redemption to Ka, his native city where he briefly returns clearly does not still his nostalgia for childhood and innocence either. Thus, "our traveler," as the narrator calls him, embarks on his cathartic journey to Kars (a passage in space and time) in search of happiness, poetic inspiration, and perhaps, God. The journey is cathartic, for as the traveler watches the snowy landscape from his seat in the bus, he felt "cleansed by memories of innocence and childhood" (4). 
Critics have pointed to the play between the name Ka, Kars, and the Turkish title of the novel, Kar. The remoteness of the setting from Turkey's cultural and political centers, Istanbul and Ankara, respectively, has also drawn critical attention.

Furthermore, the city's historical identity negotiated between the Ottoman and Russian Empires, Armenia, and modern Turkey, is frequently invoked in Snow, enriching the city's symbolic function. ${ }^{25}$ It stands for the inner space of Ka's quest, entailing many things, sexual desire, happiness, poetic inspiration, spiritual meaning, and most importantly, the attempt at reintegration of the estranged Turkish intellectual into the community of his people. Kars embodies a geographical cipher of isolation, a borderland where everybody is in exile: the traditional Muslim population, struck by poverty and forgotten by Istanbul and Ankara; the Islamists, including the suicidal headscarf girls and students of the religious school, a group I will later discuss in light of the term 'counter public'; the secular state officials who are strangers among the religious milieu, and the radical Islamist leader Blue, who is in hiding. Finally the two main female characters, Ipek and Kadife (now wearing a headscarf) and their father, a former communist, also lead displaced lives in Kars. Ka encounters this disparate community of exiles during his own displacement in Kars, which spans over three days. The novel brings to life the figures of this enclosed microcosm by rendering them in their individuality and letting them speak with their own voice, thus recognizing them as subjects. As Erdag Göknar points out, "[n]arrative redemption is the moral of Pamuk's world"26

Pamuk maintains that the novelist's imaginative power "makes him not just a person who explores the human realities that have never been voiced before-it makes him the spokesman for those who cannot speak for themselves, whose anger is never heard, and whose words are suppressed."27 The author embarks on this mission in Snow while at the same time acknowledging the complications giving voice to the 'other' entails. In Snow, the problem of representation is addressed in a twofold way: first, as a hermeneutic question implied in the form of the fictional biography. In this sense, the hermeneutic gap is ironically conveyed through the novelist narrator's inadequate attempt to grasp the poetic genius of his friend, analogous to Thomas Mann's narrator Zeitblom in Doktor Faustus or Nabokov's narrator in The Real Life of Sebastian Knight. The second complication pertains to representing difference in a constellation of 
unequal power positions, leading to the question of discursive authority. In Snow, the ostracized Islamists talk for themselves, and they are listened to attentively. Their voices are juxtaposed with those of the secularists. Fundamental issues, pertaining to personal happiness, politics, religion, crime, and last but not least, the meaning of the headscarf, are addressed in a framework of multiple viewpoints. Even though the state officials who stage a coup in Kars are certainly represented in an unfavorable light, the rightfulness of the Islamist players ultimately remains questionable. Furthermore, the characters in Kars are viewed from two perspectives (Ka's, and later, the narrator Orhan's), both belonging to the intelligentsia. Ka's own exilic standpoint situates him to a certain extent within the group of the marginalized, thus counteracting the problem of discursive authority, even if the narrator Orhan's frame-narrative reintroduces it. In the end, Pamuk deals with the problem thematically, by letting the residents of Kars articulate themselves the pitfalls of representation. ${ }^{28}$

In Snow, the extraterritoriality of Kars not only contains the officially marginalized 'others' of present-day Turkish society, but also conjures up specters from the city's history. The multicultural past is evoked through the depiction of architectural sites, some in ruins, some still in use. As I will elaborate in the following, the three days that Ka spends in Kars are marked by extraordinary events: Due to a snow storm, the city's transportation lines with the external world are cut off. Taking advantage of this total isolation, an itinerant actor, named Sunay Zaim, a passionate proponent of the secular state ideology and Brechtian theater, stages a (would be) military coup with the participation of $Z$. Demirkol, a ruthless figure and leader of a special task force unit of the Turkish secret police. Their goal is to suppress the rise of political Islam (and the Kurdish separatist movement) just before municipal elections in Kars, and especially, intimidate the youth in the city's religious schools. The "revolution" that breaks out onstage and turns violent toward the spectators during Zaim's performance of a didactic play from the early era of the Republic, is represented as a farce, yet the narrative leaves no doubt that in the diegesis violence is actually occurring with tremendous impact on the fates of $\mathrm{Ka}$ and other characters. Even when $\mathrm{Ka}$ is drawn inadvertently into the midst of this turmoil in the hours and days following the coup, his attention is more often than not turned away. Oblivious to the violence around him, he is either fixated 
on a poem that he received through some kind of higher inspiration after his arrival in Kars, or he looks contemplatively at the beauty of his surroundings, which seem transformed under a white blanket of snow: "How white and how mysterious! There wasn't a soul in the three-story Armenian building that now housed the city council. . . Ka passed an empty one-story Armenian house, its windows boarded up. As he listened to his footsteps and the sound of his short breaths, he could feel the call of life and happiness as if for the first time, yet he also felt strong enough to turn his back on it " (163-4). He continues his walk conjuring up Kars's Russian, Ottoman, Armenian, and Turkish past inscribed in the sites, such as the residential palace and other buildings. " $A$ little farther down the road, in front of another old Armenian building just as peaceful and beautiful as the rest, a tank moved past an adjoining empty lot, slow and silent, as if in a dream" (164). The juxtaposition of the Armenian building with the tank, the symbol of the military force, embodies the repression of the historic heterogeneity of the locale by the ideology of the secular Turkish state. The notion of a cohesive and homogenous 'Turkish identity' was created by the erasure of ethnic, cultural, and linguistic diversity that once defined the region. In Snow, Kars is alternately portrayed as a provincial town struck by poverty, an abandoned ghost town, and the site of potential happiness for the protagonist, bestowing meaning on his spiritually empty inner life and offering him the gift of poetic inspiration.

Ka does not pay attention to the gunshots, instead admiring the beauty of the silent night; he stops at an Armenian church to pay his respects. The imagery of the passage implies the tragic disappearance of the Armenian culture from Turkey: “. . the trees in its gardens were dripping with icicles and looked like ghosts. The yellow street lamps cast such a deathly glow over the city that it looked like a strange sad dream, and for some reason Ka felt guilty. Still, he was mightily thankful to be present in this silent and forgotten country, now filling him with poems" (166, emphasis mine). As I argued before, Snow is a novel of the oppressed, those who are pushed to the margins and erased from national narratives. As a member of the ruling elites, Ka feels the burden of a collective guilt. The site of the "deadly glow over the city" suggests both the neglect of contemporary Kars by the centers of political and cultural power, and it reminds of the destruction, frozen in time and space, in the Armenian church garden. 
The Armenian past resonates abundantly in the novel, even if the annihilation of the Armenians during World War I is not explicitly addressed. When fictional narrator Orhan visits Kars after Ka's death, he goes to the National Theater building, now turned into an appliance depot, to trace the lost manuscript of poems written by his deceased friend:

As we stood in the dark and mildewy auditorium-turned warehouse surrounded by ghostlike forms of refrigerators, stoves, and washing machines, he [the owner] pointed out the sole remaining trace of that last performance: the huge gaping hole made by the bullet that had hit the outside wall of Kirkor Çizmeciyan's private box. (16I)

The bullet hole is an inscription that contains the code of violence repeating itself: the bullet was actually fired toward the Islamist audience during the military coup on stage. Obviously, this particular one missed its target or was intentionally shot out of focus, thus hitting the outer wall of the old box. But Kirkor Çizmeciyan is not a random name; it is an Armenian name, conjuring up from the rubbles of history a denizen who once participated in the city's cultural life. The narrator informs us that, "in the first decade of the twentieth century, Kirkor Çizmeciyan, a wealthy leather manufacturer, had sat [in the private box] with his family, dressed from head to toe in fur" (I59). Striving for uniformity, the bullet of the state power hits the particular, it aims to destroy manifestations of difference. In the context of the plot, this target is Islamist identity politics. Accordingly, the bullet kills, among others, Necip, an Islamist teenager at the local religious school. Necip was aspiring to become the first Islamist science-fiction writer, and had won Ka's sympathies with his childish idealism. After the bloody coup at the theater, $\mathrm{Ka}$ is led to the morgue by the secret police to identify Necip's body. Ka is at the verge of breaking in tears, but restraining himself, he kisses Necip on the cheeks. “He kissed him, he explained, because the teenager had had a pure heart" (I86). The other bullet, almost simultaneously aiming at the box once occupied by the Armenian leather manufacturer, suggests in its symbolism that the bullets are two separate manifestations of the same violent repression of difference, employed by the secular state and army for the sake of guarding modern Turkey's national identity. One bullet kills the Islamist boy Necip literally, the other the historic figure Çizmeciyan 
symbolically. As I already indicated, however, the reasons behind the disappearance of the Armenian culture from the region remain unexplored. ${ }^{29}$ At times, it seems that the author juxtaposes the multicultural components of the Ottoman past in an undifferentiated manner, solely expressing nostalgia for the bygone diversity:

Ka had a strong sense of the people (Armenians who traded in Tiflis? Ottoman pashas who collected taxes from the dairies?) who had once led happy, peaceful, and even colorful lives here. Gone were now all the Armenians, Russians, Ottomans, and early Republican Turks who had made this city a modest center of civilization, and since no one had come to replace them the streets were deserted. (132)

Yet, my above analysis shows that Pamuk's evocation of the past through spatial symbolism entails a historical critique. I would thus conclude that Snow challenges, at a metanarrative level, the official homogenizing identity discourse of the Republican era, inviting to a rethinking of 'Turkish identity.' The symbolic function of the two bullets I discussed points expressly to this reflection. Based on such a premise, Pamuk establishes multiple alliances between various figures of displacement; thus connecting the Armenians of the past and the Islamist residents of present-day Kars. By giving the Armenian merchant a name and place in history, and by having Ka kiss the dead Islamist boy, Pamuk offers a double narrative redemption of Ottoman-Turkish history and culture. $^{30}$

The play the Jacobin character Sunay Zaim performs on the stage of the National Theater is titled "My Fatherland or My Head Scarf." Written in the early years of the Republic, "this short play was performed frequently in lycées and town halls all over Anatolia, and it was very popular with westernizing state officials eager to free women from the scarf and other forms of religious coercion. But after the fifties, when the ardent patriotism of the Kemalist period had given way to something less intense, the piece was forgotten" (147). The narrator describes it as desperately old-fashioned and primitive, yet with a sound dramatic structure: A woman is walking down the street with a black scarf; after some thinking, she takes her scarf off, liberating herself. She manifests her defiance against the religious coercion posed on her by the social 
environment by burning the scarf. Just as fanatic Muslim men violently attack her, she is rescued by the soldiers of the Turkish Republic.

The headscarf play and its performance at the Kars National Theater leads us back to the contested meanings of this cultural symbol in present-day Turkey and the opposing patterns of narrative pertaining to Turkey's social transformation. Thus, in Snow, the headscarf as a multiply encoded object functions as a key to understanding the conflict inherent in the formation of modern 'Turkish identity'. The modernist public sphere in Turkey, which emerged with the foundation of the Republic in the 1920s, has been transformed in the last two or three decades through challenges posed by alternative models. As I indicated at earlier, these challenges are viewed within the dualistic vocabulary of 'progress' and 'backwardness' or 'modernity' and 'tradition' by the followers of the modernization project, initiated by Kemal Atatürk. On the other hand, recent critics of this project propose to transcend the binarisms by analyzing the social transformation in more complex terms, thereby rethinking Turkish identity politics.

In order to elucidate this framework, I will briefly return to Nilüfer Göle's model. Göle emphasizes the crucial role that the public sphere played in the Turkish project of modernization, stating that the new structure of state and society and their relation to each other were defined by the French word "laicité."31 Laicité requires a secular public life where religious practices and manners are left behind. In contradistinction to Habermas's model of the public sphere created by the liberal bourgeois ideology, the Turkish public sphere was the outcome of an authoritarian state, and controlled by the secular elites. In this context, Defne Suman highlights the differences between the Western and the Turkish public spheres by referring to Western feminist schools of criticism that show women's and non-bourgeois classes' exclusion from the dominant bourgeois public sphere. In the Turkish case, Suman argues, secularization was signified by the Westernized relations between women and men. It was a realm that enhanced the visibility of the Turkish woman in a European appearance. However, the seeming emancipation of women in the modern Turkish public sphere of the early decades of the Republic rests on the premise of bracketing particularistic identities. ${ }^{32}$ One can enter the public sphere only on the condition of 
leaving differences behind. Thus, in spite of the seeming gender and class equality, the Turkish model of the modern public sphere rests on not only a secularist but also universalist conception of the citizen. Suman concludes that

In [the] Turkish case, particularistic identity was identified with religious and ethnic identity and one was expected to leave all his or her religious practices to enter public realms. Those who cannot conform [to] a new way of life then, were [the] non-Westernized Muslim population and peasants. Until [the] 1950's peasants were not allowed to walk on streets of Istanbul because it was thought that they were distorting the picture of [the] Westernized way of life. What we can say as a result then, is that neither Habermas's bourgeois conception nor [the] Kemalist secular conception of public sphere do appear as democracy providing equal access to all citizens. ${ }^{33}$

Pamuk represents the Islamist groups in Kars, and most notably the headscarf girls who are coerced to take off their scarves in order to enter the public arena, i.e., schools, within the framework of such a model of public sphere. According to the social thought sketched above, these groups evoke Nancy Fraser's definition of alternative groups as "subaltern counter publics," in opposition to the dominant public. ${ }^{34}$ Accordingly, the East-West trope permeating Snow is not primarily concerned with a split between traditional Islam and the Western mode of life, but with the "subaltern counter publics." This new group of Islamists manifests a new lifestyle and asserts itself through a conscious identity politics. As illustrated by scholarly positions challenging modernization theory, this new identity politics cannot be equated with the traditional Muslim way of life. ${ }^{35}$

The domination of the Turkish secular public sphere which persisted till the 1980s encountered major challenges after 1983, thus becoming an arena of competing social movements, such as the Islamist, Kurdish, Alevite, and liberal movements. ${ }^{36}$ The Islamist current emerging as a counter public and requesting recognition and legitimization of Muslim identity constituted the foremost challenge to the secular public sphere. Secular elites viewed this transformation as an invasion of their public sphere. This request, along with the Islamist critique of Westernized lifestyles and the claim to 
moral control of the public sphere, became most visible through the Muslim female students' insistence to be allowed to attend university classes in Islamic dress. In Göle's and Suman's analyses, Islamism parallels feminism, in that it introduces the private realm into the public sphere, making religion (instead of sexuality), a publicly discussed issue. The Islamist public manifests a "declaration of difference," fighting for becoming active actors in society. ${ }^{37}$

The novelistic discourse of Snow contributes to this line of socio-cultural analysis. Pamuk reflects on the potential of true democracy in his society by turning his attention to members of an officially excluded group, the Islamists, and rendering them unforgettable fictional characters, such as Kadife, the head-scarved sister of Ka's lover, Ipek and the embodiment of the new, "conscious" and educated Islamist woman; the radical Islamist leader Blue; the teenager Necip who is killed during the theater coup; his friend Fazil, and others.

Let us return here to the Kars National Theater and the performance of "My Fatherland or My Headscarf." The play is attended by a mixed audience that night, ranging from representatives of the secular establishment to unemployed locals and the students of the religious school. The reception of the play by this audience demonstrates intriguingly that the antagonism between Islam and freedom the play advances has collapsed. The symbolism that once conveyed in a transparent fashion an irreconcilable duality in the discourse of the enlightened public sphere, causes a great deal of confusion in the contemporary audience:

When they had heard that the play was entitled My Fatherland or My Head Scarf, they assumed it would be a consideration of contemporary politics, but aside from one or two octogenarians who remembered the original from the old days, no one expected to see an actual woman onstage wearing a head scarf. When they did, they took it to be a sort of head scarf that has become the respected symbol of political Islam. (147) This is clearly a misinterpretation, for political Islam did not exist at the time of the play's genesis and the headscarf was not meant to evoke respect. When the female figure onstage removes her scarf "launching herself into enlightenment . . the audience was at first terrified" (148). The secularists feared that the removal of the headscarf 
would incite a riot of political Islamists or traditionalist locals in the back rows. For these secularists could no longer imagine that the state would force women to remove their headscarves as in the early years of the Republic. For the fear of worse, they were resigned to the fact that they had to live in Kars with the increasing pressure of this new 'counter public,' the Islamists. Each scene of the play stirs up new confusion. The middle-aged actress who plays the self-liberating young woman is Funda Eser, Sunay Zaim's long-time partner and also a belly dancer:

As to the Republicans in the front rows, they weren't very happy with the situation either. Having expected a bespectacled village girl, purehearted, bright-faced, and studious, to emerge from beneath the scarf, they were utterly discomfited to see it was the lewd belly dancer Funda Eser instead. Was this to say that only whores and fools take off their head scarves? (149)

This confusion suggests that the Republican ideology can only reenact itself as a farce and that its domination of the public sphere has outlived itself. To stage this play is an anachronism, analogous to the rigid secular nationalist standpoint that insists on excluding the 'other' (religious and ethnic particularities) from the 'Turkish identity'. Times have changed and the challenges to the secular public sphere are real, which means that 'Turkish identity' is under negotiation. Mixed reactions from the audience, such as laughter, horror, and anger at every scene of the play intensify the ambiguity to the once transparent meaning of the didactic drama. The actor Sunay and his conspirators are able to agitate the public, especially the Islamist students, to a certain extent. Yet the reaction from the audience does not go beyond erratic screams of protest. Nevertheless, Sunay's gang carries out its plans, opening fire on the spectators and killing several randomly, including the student Necip. The gunshots are fired, while the audience is still watching the events as spectacle; the erupting violence thus signifies a strange merging of art and life. ${ }^{38}$ While the play within the play allegorically points to the imposition of the Kemalist ideology through military power, mirroring the three successive military coups of the 1960's, 70's, and 80's in the real history of Turkey, it also points in a self-reflective gesture to its own nature, a mere play. The nightmarish atmosphere in the city streets in the wake of the coup signals to the 
reader that the events follow their dream-like logic and belong in multiple ways into the world of fiction: First, everyone, including the reader, knows that the coup is temporary and illegal, its survival depending on the weather conditions. When roads reopen, the real state power will reestablish the status quo in Kars; secondly, because the coup was enacted as a play, and thirdly, because the novel's fictional universe unfolds at the intersecting strategies of mimesis and fantasy.

There is a second play within the play in Snow dealing with the headscarf issue. Merging art and life, this second play moves the novel towards its denouement. In this second instance, Kadife, the head-scarved sister of Ka's lover lpek, agrees to Sunay's pressure to remove her headscarf while acting in a play written by the actor in return for her lover radical Islamist Blue's release. The gun that Kadife fires toward Sunay onstage happens to be loaded, killing the secularist actor. Multiple conflations of play with reality obscure the meaning of this episode. Is it to be understood as the revolt of the Islamists against state oppression, or the revenge of Necip, the Islamist student, killed by a bullet during the previous play onstage? The information that Kadife's gun was loaded accidentally seems to weaken these possibilities, but does not exclude them. Even though violence is oftentimes enveloped in play, Snow does not leave any doubt that it is real within the storyline, thus alluding to the potential grim outcome of the tensions between the secular power structure and the Islamist counter public in Turkish society. Opening with the suicide of the headscarf girls, the novel proceeds through several acts of violence, all related to these tensions. Early on in the novel, a radical Islamist shoots point blank in a pastry shop the director of the Institute of Education whose task had been barring the girls with covered heads from the classrooms. Bloodshed then occurs twice at the Kars National Theater, killing Islamists in the audience and the secularist actor on stage, respectively. Finally, Blue and Ka are both murdered, the former in Kars at a raid to his hiding place by the state forces, the latter in Frankfurt, allegedly in a revenge act. As I mentioned at the beginning, the motive leading to Ka's denunciation of Blue pertains to his pursuit of personal happiness, his fear of losing Ipek, with whom Ka plans to leave for Germany, to the rival Blue. In the end, Ka's pursuit of happiness is not fulfilled, for Ipek breaks her promise to follow him. Blue's denunciation by $\mathrm{Ka}$ is revealed to the reader toward the 
end of the novel through the narrator Orhan's reconstruction of the events. Even if this conjecture reflects accurately the personal reasons behind Ka's treason, Ka's action still associates symbolically with the secular elites' coercion of the Islamist movement. Clearly, Snow leaves the boundaries between passion and politics blurred.

Despite such ambiguities, Snow as a socio-political commentary delivers a legible message. The analysis I presented illustrates Pamuk's rethinking of the question of 'Turkish identity' beyond polar oppositions under which it is contested at the present. In contrast to the secular establishment that wishes to halt the entry of the new religious life style into the public sphere, the author approaches the proponents of the new Islam in an unbiased fashion. By establishing ways of communication between the figures of the Istanbul intelligentsia, Ka and Orhan, and the Islamist residents of Kars, Pamuk tests in Snow the possibility of a pluralistically defined 'Turkish identity.' Analogous to the critique, articulated in new historical and social research, Pamuk offers a more complicated reflection of Turkey's social transformation than the premise of linear progress put forward by modernization theory. By focusing on particularity instead of the nationalist notion of uniformity, Snow articulates an appeal to create a more tolerant, more diverse, more democratic Turkish society. The figure of displacement serves as the vehicle through which Pamuk carries out his experiment. The author's choice of a marginal geographic location with a multicultural historic background instead of metropolitan centers serves a crucial purpose. Kars embodying a space of exile allows unusual encounters to come about, such as the dialog between the provincial Islamist Blue and the urban poet Ka. Even if the novel is far from presenting reconciliation, the enactment of these unlikely interactions expresses the novelist's proposition to negotiate 'Turkish identity' in pluralistic terms.

Pamuk expands his novelistic experiment with 'Turkish identity' to Frankfurt, the counter pole on Snow's exilic axis. In conclusion, I will outline a short intertextual episode pertaining to Frankfurt that deserves attention as a complementary dimension of Pamuk's representation of 'Turkish identity' through the theme of exile. Before traveling to Turkey, Ka buys a charcoal gray coat from the Kaufhof in Frankfurt. The salesperson assisting him is one by the name of Hans Hansen, just like Thomas Mann's blond, blue-eyed character in Tonio Kröger. Ka uses this name, when he fabricates a story 
for Blue, convincing him that he, Ka, will be the emissary of the Islamists and other oppressed groups in Turkey, when he returns to Germany. In the fabricated story, Hans Hansen is the editor of a prominent newspaper, and he will publish the manifesto of the oppressed. Ka is acquainted with Hansen, so the story goes; he has been even invited to dinner to their house, and has met his charming wife Ingeborg, the double of another blond, blue-eyed figure from Tonio Kröger, and their happy, well-mannered children. Just like Tonio, Ka admires the German family and desires to be included in their intimate sphere. Ka tells Blue that, after the (imaginary) evening at the (fictional) German family's home, they only interacted briefly when Ka published a report on death and torture in Turkey in Hansen's newspaper. He longed to be invited to the Hansen home again: "But he never called me again. From time to time I played with the idea of writing him a letter, to find out what I had done wrong, to ask him why he'd never invited me back to his house" (233). Similar to Mann's Tonio, Ka remains excluded from the community of the happy ones. Given that Pamuk is an ardent proponent of Turkey's entry into the European Union, it is feasible to read the Hans Hansen episode as an articulation of the author's desire that his country be included in the European Union. ${ }^{39}$ By leaving Ka exiled from the community he longs to join, Pamuk addresses Turkey's uncertain future vis-à-vis the European Union, pleading once again for a politics of inclusion, this time on a larger scale.

\footnotetext{
I Orhan Pamuk, Snow, trans. Maureen Freely (New York: Vintage International, 2004). All quotations are taken from this edition. The page numbers are indicated in parenthesis within the text.

${ }^{2}$ A good example of such strategy is Ka's encounter with Sheikh Saadettin, a local religious figure who summons Ka to his house. When Ka follows the offer and meets the Sheikh, he seems to become seriously engaged in a conversation with the Sheikh on transcendence and his own search for faith: "'The snow reminded me of God,' said Ka. 'The snow reminded me of the beauty and mystery of creation, of the essential joy that is life." Yet he also admits soon thereafter that he had three glasses of the Turkish liquor raki, before he came (96). His self-confessed intoxication relativizes the relevance of the religious conversation and leaves the encounter with the religious authority inconsequential, except for the fact that, while still at the Sheikh's house, he "receives" another poem through what he believes to be a higher source of inspiration. The first visit of Ka's old university friend, Muhtar, now a political Islamist, to the Sheikh's house follows a similar pattern.

${ }^{3}$ Orhan Pamuk, "In Kars and Frankfurt," Other Colors, trans. Maureen Freely (New York: Alfred A. Knopf, 2007) 226-36, here 232.

${ }^{4}$ In Pamuk's view, the novelist's involvement in politics through the fictional work always occurs indirectly: "A novelist's politics arise from his imagination, from his ability to imagine himself as someone else." "In Kars and Frankfurt" 229.

${ }^{5}$ In the general elections of July 22, 2007, the moderately Islamic Justice and Development Party (AK Parti) that has been governing Turkey for the last five years won a sweeping victory. The following appointment
} 
by the parliament of Abdullah Gül as President who had been a member of the same party, became the most divisive issue of the summer months, for Gül not only represents Islamic views, but has also a covered wife. On February 22, 2008, Gül approved, as the first step of a larger package of constitutional changes, the constitutional amendment to lift the headscarf ban at public universities. In a few days, secularists counteracted by applying to the Turkey's Supreme Court to press charges against the ruling party claiming that its actions transgressed the Turkish constitution. The outcome of the court's ruling may take several months. In view of hard-core secularists, behind its moderate identity, Turkey's leading party has a hidden agenda, namely transforming the country into an Islamic state. Other factions of the secular intelligentsia argue that democracy can only flourish by promoting liberal values, including more religious freedom.

${ }^{6}$ The crisis has its roots in part in the huge migration movement from rural Turkey to metropolitan centers in the late decades of the twentieth century. While the first generation of migrants were uneducated peasants, their children entered secondary and higher education, aspiring to become professionals and middle-class citizens. It is these younger generations that have claimed a place in the public sphere while asserting their identities as Islamic. Today, more than 70 percent of Turkey's population lives in big cities. Sabrina Tavernise describes the result of this influx as follows: "Millions of rural, observant Turks migrated to the cities in the 1980s, became middle class in an economic boom, and began to mix with their secular, urban counterparts in malls, parks and, by the late 1990s, in universities," "In Turkey, a Step to Allow Head Scarves," The New York Times 29 Jan. 2008: A3. See also Tavernise, "Under a Scarf, a Turkish Lawyer Fighting to Wear It," The New York Times 9 Feb. 2008: A4.

${ }^{7}$ Resat Kasaba, "Kemalist Certainties and Modern Ambiguities," Rethinking Modernity and National Identity in Turkey, eds. Sibel Bozdogan and Resat Kasaba (Seattle, University of Washington Press, 1997) 15-36, here 16. See also Çaglar Keyder, "Whither the Project of Modernity: Turkey in the 1990s," Rethinking Modernity, 37-5I. Keyder explains the crisis of the Turkish project of modernity by referring to its nature as a "modernization from above," in which not all of the members of Turkish society participated. Keyder states: "The gap between the modernizing elites, whose discourse diverged radically from what could be popularly appropriated, and the voiceless masses gradually emerged as the axis around which the subsequent history of Turkish society was played out. No mediation developed between the modernizing discourse of the elites and the practice of the masses. Consequently, the Westernist ideal came to be identified with the statist and authoritarian stance of the modernizers. In response, a resistance culture, packaged as authentic, evolved to challenge the modernizing imposition" (45).

${ }^{8}$ Deniz Kandiyoti, "Introduction: Reading the Fragments," Fragments of Culture (Fragments), eds. Deniz Kandiyoti and Ayse Saktanber (London, New York: I. B. Tauris \& Co Publishers, 2002) I-2I, here 2. 'Jenny B. White, "The Islamist Paradox," Fragments, 191-217, here 206.

${ }^{10}$ White 206.

"Yael Navaro-Yashin argues that by conflating class with identity politics, the Islamist discourse itself creates a set of binary oppositions: "Islamist social critique too easily maps the lifestyle of Islamists onto that of Turkey's poor or Turkey's economically under-privileged. The associations of wearing 'Western clothes' and leading 'westernized lifestyles' are too easily conflated with 'Turkey's wealthy' in this political discourse. Accordingly, westernization was imposed on 'Turkish society' by 'elites'. And, even though 'the elites' developed a lifestyle 'foreign to Turkey,' 'the rest of Turkey' (also referred to by Islamists as 'the other Turkey') kept 'its values,' or has attuned itself to its true conscience since. Islamists have projected all sorts of lifestyles that they defined as 'improper' onto 'Turkey's rich'. 'The real Turkey' or 'the culture of the people,' as Islamist intellectuals have often said, is not about using 'Western things'. A binarist discourse on class went hand-in-hand with Islamists' politics of identity." Navaro-Yashin points out that the self-fashioning of 'Islamic authenticity' was in fact a product of the consumer market. "The Market for Identities: Secularism, Islamism, Commodities," Fragments, 22I-53, here 248. See also Ayse Saktanber on class and Islamic subcultures, "'We Pray Like You Have Fun': New Islamic Youth in Turkey between Intellectualism and Popular Culture," Fragments, 254-76.

${ }^{12}$ The White Castle and The Black Book offer outstanding examples of such confusion and blurring of identities. In Snow, Pamuk uses a similar strategy by having the narrator Orhan reenact the protagonist Ka's experiences in Kars.

${ }_{13}^{13}$ Pamuk, "In Kars and Frankfurt" 228.

${ }^{14}$ Said writes: "Exile is strangely compelling to think about but terrible to experience. It is the unhealable rift forced between a human being and a native place, between the self and its true home: its essential 
sadness can never be surmounted. And while it is true that literature and history contain heroic, romantic, glorious, even triumphant episodes in an exile's life, these are no more than efforts meant to overcome the crippling sorrow of estrangement. The achievements of exile are permanently undermined by the loss of something left behind for ever." "Reflections on Exile," Edward W. Said, Reflections on Exile and Other Essays (Cambridge, Massachusetts: Harvard University Press, 2000) 173-86, here 173.

${ }^{15}$ John Updike, quoted in Nicholas Wroe, "Occidental Hero," rev. of Snow, by Orhan Pamuk, The Guardian 8 May 2004, Guardian Saturday Pages <http://books.guardian.co.uk/print/0.3858,4918325-

110738,00.htlm>, p. I. We read in Wroe's review: "In Turkey, the launch of a new Pamuk novel has more in common with the release of a Hollywood film than the publication of a book. There is media saturation and considerable cachet in being seen with his latest work" (p. 2).

${ }^{16}$ Brodsky was born in 1940 in Leningrad and went to exile in 1972. He now lives Massachusetts and New York City. He was awarded the Nobel Prize for Literature in 1987. See Altogether Elsewhere: Writers on Exile, ed. Marc Robinson (Boston: Faber and Faber, 1994) 406.

${ }^{17}$ Joseph Brodsky, "The Condition We Call Exile," Altogether Elsewhere, 3-I I, here 4.

18 Said 173-4.

19 Said 173.

${ }^{20}$ Orhan Pamuk, Istanbul: Memories and the City, trans. Maureen Freely (New York; Vintage International, 2006).

${ }^{21}$ Quoted in Said 174.

22 Pamuk's construction of Istanbul's melancholy is based on the works of four Turkish literary figures, whom he calls “Four Lonely Melancholic Writers," Yahya Kemal, Ahmet Hamdi Tanpinar, Resat Ekrem Koçu, and Abdülhak Sinasi Hisar. These writers' self-fashioning by turning toward the Ottoman past becomes a major source of inspiration for Pamuk.

${ }^{23}$ Critic Erdag Göknar identifies four major areas for Pamuk's oeuvre: Ottoman history in a European context; the transition from Ottoman Empire to modern Middle East; the early-twentieth century Kemalist cultural revolution, and the legacy of all three on present-day Turkey. He argues that Pamuk's fictional characters, like the author himself, question their (often imposed) identities within this framework. Pamuk represents the contradictions inherent in these trends of Ottoman-Turkish history from a multiplicity of perspectives, thus destabilizing the historical discourse of linear progress. "Orhan Pamuk and the 'Ottoman' Theme,” World Literature Today 80.6 (2006): 34-38.

${ }^{24} \mathrm{He}$ also shares with his creator Pamuk a work of fiction (The Black Book) and a daughter named Rüya. As I have already pointed out, such playful doublings frequently occur in Pamuk's fiction.

${ }^{25}$ In its early history, $\left(9^{\text {th }}-I^{\text {th }}\right.$ centuries) Kars served as the capital of Armenian dynasties. Between the $1 \mathrm{I}^{\text {th }}$ and the $16^{\text {th }}$ centuries, the city was ruled the Byzantine Empire, Georgia, Seljuk Turks, and Mongols, until it was captured by the Ottomans in 1534. In the nineteenth century, the city was seized by the Russians several times, until it was subjugated to Russia at the end of the Russo-Turkish war 1877-78. In the period following the war, thousands of Muslims emigrated from the region to Turkey, while many Armenians returned to the region, along with other immigrating populations, such as Greeks and Russians from other parts of Turkey and Transcaucasia. At the wake of the First World War, Kars was negotiated several times between Russia, Armenia and Turkey, until it was included into the Turkish territories with the above-mentioned treaty in 1921. Kars became yet again a contested borderland between the Soviets and Turkey in 1945, finally maintaining its status quo through Churchill's intervention. The ethnic plurality that signified the city's past has largely diminished since its inclusion into the Turkish Republic in I92I, still two years short of it official foundation.

${ }^{26}$ Göknar 37.

${ }^{27}$ Pamuk, “In Kars and Frankfurt” 229.

${ }^{28}$ The conclusion of the novel offers the best example of Pamuk's treatment of the problem of representation. Here, Pamuk also offers a commentary on the rift between Turkish intelligentsia and provincial population, a major theme of modern Turkish literature. The episode indicates that the novel will not close the gap. At the end of the novel, the narrator Orhan is about to leave Kars, where he attempted to reconstruct his deceased friend Ka's days in that remote city, without ever recovering Ka's manuscript of poems. At the train station, the denizens of Kars, who had known Ka, have gathered to say goodbye to the author Orhan, the intellectual from Istanbul. "I turned back to Fazil [a former student at the religious school and friend of Necip who was killed at the National Theater, Ü.G.] and asked him whether he knew now what he might want to say to my readers if ever I was to write a book set in Kars. 
'Nothing.' His voice was determined. When he saw my face fall, he relented. 'I did think of something, but you may not like it,' he said. 'If you write a book set in Kars and put me in it, l'd like to tell your readers not to believe anything you say about me; anything you say about any of us. No one could understand us from so far"' (425-6).

${ }^{29}$ See Christopher Hitchens, “Mind the Gap," rev. of Snow by Orhan Pamuk, The Atlantic Monthly, October 2004, 188-193. Hitchens argues that, "courage is an element that this novel lacks" (192). His critique pertains primarily to Pamuk's undifferentiated treatment of the Armenian culture of the region. Alluding to Taner Akçam's recent scholarship on the Armenian genocide and his critique of the Turkish state policy in the matter, Hitchens continues that Akçam (a Turkish scholar) was "initially forced to publish his findings as one of those despised leftist exiles in Germany-whereas from reading Snow one might easily conclude that all the Armenians of Anatolia had decided for some reason to pick up and depart en masse, leaving their ancestral properties for tourists to gawk at. As for the Kurds, Pamuk tends to represent them as rather primitive objects of sympathy" (192).

${ }^{30}$ As is well known, the Armenian culture in Anatolia perished before the foundation of the Republic of Turkey.

${ }^{31}$ Nilüfer Göle, "Gendered Nature of the Public Sphere," Public Culture, I0.I (1997): 6I-8I, here 64. See also Defne Suman, "Elite, Bourgeois Others: A Non-Conformist Approach to Western and Non-Western Context of Public Sphere," unpublished seminar paper, Department of Sociology, Bogazici University, Istanbul, 1-16, here 2.

32 Suman 3-4.

${ }^{33}$ Suman $4-5$, brackets mine.

${ }^{34}$ Suman 5.

${ }^{35}$ As White and Navaro-Yashin argue, the model of such a counter public is far from being "pure," containing conflicts and contradictions pertaining to gender and class.

${ }^{36}$ See Göle 68; Suman 6.

${ }^{37}$ Suman discusses the process of subjectivation, i.e., becoming an active actor in society, in reference to Alain Touraine's concept of "Subject" and Seyla Benhabib's "concrete other." (7-I2). For an analysis of the tensions between feminism and multiculturalism see lan Ward, "Shabina Begum and the Headscarf Girls," in Journal of Gender Studies 12. 2 (2006): I I9- I3I.

${ }^{38}$ Referring to the coup de'etat, carried out onstage by the actor Sunay, critic Christian Caryl writes: "Though the precedent is never explicitly mentioned, both his [Sunay's] plans and his high-modernist aesthetics seem to owe a lot to the Italian writer Gabriele D'Annunzio and his founding of an early fascist mini-state in Fiume after World War I," "The Shizophrenic Sufi," rev. of Orhan Pamuk, Snow, The New York Review of Books 52.8 (2005): 26-28, here 26. http://www.nybooks.com/articles/I 7975?email.

${ }^{39}$ Alluding to the rise of anti-Turkish sentiments in Europe, Pamuk states; "It is one thing to criticize the democratic deficits of the Turkish state or find fault with its economy; it is quite another to denigrate all of Turkish culture - or those of Turkish descent here in Germany whose lives are among the most difficult and impoverished in the country. As for Turks in Turkey: When they hear themselves judged so cruelly, they are reminded yet again that they are knocking on a door and waiting to be let in, and of course they feel unwelcome." "In Kars and Frankfurt" 234, my emphasis. 